\title{
A FÚRIA DO FÜHRER: UM ESTUDO DAS ESTRATÉGIAS DISCURSIVO-PRAGMÁTICAS PRESENTES NUM "VIRAL" DO YOUTUBE
}

\author{
Júlio César Araújo* \\ Rafael Rodrigues da Costa**
}

Resumo: Algumas teorias sobre pressuposição (STRAWSON, 1952; KEENAN, 1971) em enunciados e sobre cenas de enunciação (MAINGUENEAU, 2008) são revisitadas neste artigo, cujo objetivo é identificar como e onde os pressupostos pragmáticos aparecem num corpus composto de quatro vídeos postados no repositório Youtube. Tais vídeos são parte de um fenômeno viral da internet e reproduzem uma mesma cena do filme alemão $A$ Queda, acrescendo a ela legendas em que o conteúdo original do filme dá lugar a diálogos sobre temas contemporâneos. A análise nos autoriza a concluir que a figura de Adolf Hitler, principal personagem do trecho de filme reproduə̧ido, passa por uma mudança de cenas enunciativas englobantes e genéricas, a partir da qual é possivel reinseri-lo em determinados contextos. Dai emergem pressuposições que ora o satirizam, ora o ridicularizam.

Palavras-chave: Cena enunciativa. Pressuposição. Web 2.0. Viral. Adolf Hitler.

\section{INTRODUÇÃO}

No jargão científico, um vírus designa um parasita capaz de invadir e infectar organismos vivos. A capacidade de se espalhar e tomar de assalto o hospedeiro faz da imagem do vírus uma metáfora poderosa para designar modos pelos quais a comunicação mediada por computador (doravante CMC) pode se expandir, a partir das intervenções de seus usuários, sobretudo na internet ${ }^{1}$.

As práticas de linguagem que se renovam ou passam a existir no ambiente virtual parecem ser tantas quanto a nossa imaginação permitir. É fato que a internet e outros meios digitais, como o telefone celular, tiveram papel decisivo na disseminação de gêneros do discurso

\footnotetext{
* Universidade Federal do Ceará. Professor do Programa de Pós-Graduação em Linguística, onde coordena o grupo de pesquisa Hiperged. Doutor em Linguística pela UFC. Email: araujo@ufc.br

* Universidade Federal do Ceará/Faculdade Estácio do Ceará. Doutorando em Linguística pela UFC e professor do Curso de Jornalismo da Faculdade Estácio do Ceará. Mestre em Linguística pela UFC. Email: rafaelrg@gmail.com

${ }^{1}$ De acordo com a mais recente Pesquisa Nacional por Amostra de Domicílios (PNAD), do Instituto Brasileiro de Geografia e Estatística (IBGE), o percentual de brasileiros de dez anos ou mais de idade que acessaram ao menos uma vez a Internet pelo computador aumentou $75,3 \%$ entre 2005 e 2008, passando de 20,9\% para 34,8\% das pessoas naquela faixa etária, ou 56 milhões de usuários.
} 
emergentes (TROSBORG, 2000; MARCUSCHI, 2004; ARAÚJO, 2004), capazes de atualizar ou mesmo repaginar gêneros preexistentes, sob o signo da hipertextualidade digital. Aqui, subjaz o pressuposto de que os gêneros são uma instância fundamental da comunicação humana, conforme assinalou Bakhtin (2000 [1979], p. 281). O pensador russo, nos idos dos anos 20 do século passado, já autorizava a pensarmos como hoje, observando os gêneros na sua dialética entre o já dado e o novo. À época, Bakhtin exemplificou essa postulação mostrando como a carta era absorvida pelo romance, naquilo que denominou transmutação.

Hoje, em meio ao fenômeno da convergência de mídias (JENKINS, 2008), os trânsitos simbólicos intensificam-se e as fronteiras entre os diferentes suportes da comunicação humana tornam-se menos óbvias. Dessa forma, torna-se comum a materialização de práticas que perpassam vários meios de comunicação ${ }^{2}$ ou que tornam possível a migração de conteúdos entre mídias. Nesse segundo cenário, seria possível observar fenômenos ligados aos gêneros do discurso, como a transmutação de gêneros (BAKHTIN, 2000 [1979]; ARAÚJO, 2006; ZAVAM, 2009). De fato, as mídias digitais vão, de certa forma, permitir a um usuário-produtor reinterpretar, parodiar e comentar categorias tão distintas de enunciados quanto videoclipes, novelas, filmes, assim como dar a esses mesmos usuários a possibilidade de compartilharem conteúdos de autoria própria.

Um exemplo desse potencial criador (ou ao menos recriador) de usuários-produtores muitas vezes anônimos, fora do circuito da chamada mídia tradicional, é o objeto de discussão do presente artigo. A partir de uma matriz comum, o filme alemão $A$ Queda (Der Untergang, 2004) - um premiado longa-metragem que tematiza a derrocada do nazismo na Alemanha, em abril de 1945 -, usuários do site Youtube (e também de outros sites de compartilhamento de vídeo), de diferentes origens, dedicam-se a produzir centenas de paródias $^{3}$ de uma mesma cena do

\footnotetext{
${ }^{2}$ Jenkins (2008) qualifica tal fenômeno de transmedia storytelling (ou narrativa transmidiática). Autores como Askwith (2007) remetem ao conceito ao estudarem produtos televisivos como o seriado Lost. Para ele, o programa é expressão de um novo modelo de tevê em que outras plataformas são mobilizadas pelos espectadores como forma de suplantar uma experiência meramente passiva.

${ }^{3}$ Segundo Deodato (2009), em setembro de 2009 havia cerca de 600 paródias da mesma cena de $A$ Queda no site Youtube. No final de 2009, a empresa Constantin Film, detentora dos direitos do longa, solicitou ao site Youtube a retirada do ar das paródias, sob a alegação de violação dos direitos autorais.
} 
filme. A partir de um processo de legendagem da cena, a cargo desses coautores, o ditador germânico passa a tecer comentários sobre temas tão diversos (e contemporâneos) quanto o fim da banda Oasis, os problemas técnicos do site Twitter, a crise no Senado brasileiro e assim por diante.

Nosso objetivo, no presente artigo, é identificar que estratégias discursivo-pragmáticas podem ser percebidas no resultado de tais processos de legendagem amadora. Ao transgredir os diálogos originais do filme e substituí-los por comentários de "cenas" contemporâneas, os usuários-autores dos vídeos parecem valer-se de alguns princípios da implicatura griceana, na medida em que a figura de Adolf Hitler, central nos vídeos, é recolocada sob um prisma irônico ou desmoralizante.

Para atingirmos tal objetivo, realizamos a análise de uma amostra composta por cinco vídeos. A análise é precedida pela reflexão acerca de questões de ordem mais teórica, que, esperamos, possa estabelecer os limites da análise mais específica a ser empreendida mais adiante. Realizaremos algumas considerações sobre o ambiente da web 2.0, o fenômeno pragmático das implicaturas, as cenas enunciativas, bem como sobre a validade de $A$ Queda enquanto documento histórico.

\section{REFERENCIAL TEÓRICO}

\subsection{WEB 2.0 E EMPODERAMENTO DO USUÁRIO}

Um momento peculiar da história da mídia audiovisual parece iniciar em simples cliques em botões como o de upload, possíveis a todo momento em sites como Youtube; justamente aí, na apropriação e articulação das linguagens que os usuários dos meios de comunicação se fizeram notar. Após anos servindo, de certo modo, como "cobaia" das criações dos meios de comunicação - os diversos gêneros em que se organizam os discursos do rádio, da televisão, dos jornais -, os usuários começaram a experimentar a sensação de estar no controle ou, ao menos, de possuir uma voz midiática. Em vídeos de cunho predominantemente amador, como o exemplo de "Leona - a assassina 
vingativa" 4 (figura 1), a ideia de uma nova era de autonomia exercida pelos usuários da internet parece palpável.

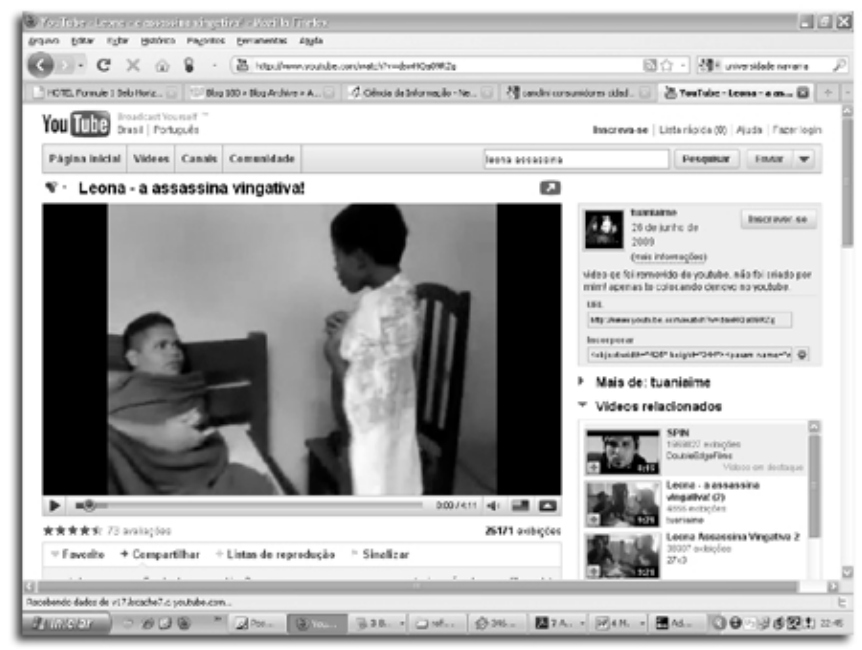

Figura 1 - Vídeo "Leona - a assassina vingativa”, produção caseira anônima postada no Youtube

A ampliação das interfaces por meio das quais os usuários podem interagir e produzir conteúdos é uma das características associadas à chamada web 2.0. Nessa fase, a internet estimula a chamada "arquitetura de participação" (O'REILLY, 2005), algo que não se fazia presente na primeira fase dos serviços online. Em redes sociais como o Twitter ${ }^{5}$, por exemplo, aplicações consagradas inicialmente pelos próprios usuários, como o comando "RT" (retweet), acabam incorporados definitivamente ao repertório de opções de uso da ferramenta.

A admissão da importância do usuário aparece na abertura à sua participação por meio de comentários ou pela possibilidade de intervir em processos colaborativos como a enciclopédia online Wikipedia. A web 2.0, seria, por assim dizer, a era da customização ${ }^{6}$ de interfaces e plataformas, ao gosto do usuário.

\footnotetext{
${ }^{4}$ http://www.Youtube.com/watch?v=dswHQa09RZg. Acesso em: 20 e 29 de julho de 2009.

${ }^{5}$ www.twitter.com

${ }^{6}$ Custom, numa tradução do inglês, refere-se a "personalização" ou "feito por encomenda".
} 
São os usuários da internet que protagonizam, quase que inteiramente, um fenômeno decorrente do descrito acima: a consagração de certos tipos de produto, como os chamados virais - ou seja, vídeos ou mesmo conceitos que adquirem popularidade na própria internet e eventualmente chegam a outros meios de comunicação. A noção de viral atualiza a ideia, já conhecida nos estudos de marketing, da propaganda boca-a-boca, ou originalmente word-of-mouth (HELM, 2000). Aqui, ela é usada em uma acepção mais coerente com os usos hoje observados e registrados na rede, em que não necessariamente se tenta vender algo a partir da divulgação em corrente de um vídeo ou outro artefato.

Num regime semiótico hipermodal (LEMKE, 2002), os significados baseados na palavra, na imagem e no som, reunidos na hipermídia, resultam na possibilidade de uma interação entre usuários e conteúdos. Sob esse prisma, pode-se explicar a facilidade de trânsito que vídeos como os do Youtube adquiriram, potencializando sua disseminação viral.

\subsection{A QUEDA: UM FILME COM PRETENSÕES DOCUMENTAIS}

"NOTA: Este filme é 100\% historicamente fiel". O aviso pode ser lido numa página do site Youtube , onde todas as partes originais do filme A Queda encontram-se reproduzidas e acessíveis. A advertência oferece a medida pela qual o filme tem sido recebido desde que estreou, em 2005: como um documento histórico capaz de reconstituir, em mínimos detalhes, a real narrativa dos últimos dias de Adolf Hitler. A Queda: Os Últimos Dias de Hitler é um drama alemão de 2005, dirigido por Oliver Hirschbiegel. O drama obteve grande sucesso comercial no país-palco dos acontecimentos narrados na trama, a Alemanha ${ }^{8}$, assim como foi lembrado em diversas premiações pelo mundo?.

Ao analisar a fidelidade do filme aos fatos que encena, Caldas (2005) afirma que $A$ Queda procura se projetar "como a própria

\footnotetext{
${ }^{7}$ http://www.Youtube.com/watch?v=NnHIWISP7zE. Acesso em 4 dez. 2009.

${ }^{8}$ De acordo com o site especializado IMDB (http://www.imdb.com/title/tt0363163/business), o filme vendeu mais de 4,5 milhões de ingressos na Alemanha.

${ }^{9}$ http://www.imdb.com/title/tt0363163/awards.
} 
realidade" (p. 4), ainda que recorra a artifícios do cânone hollywoodiano, como a divisão maniqueísta dos personagens entre mocinhos e bandidos. Essa pretensão realista estaria expressa, por exemplo, em aspectos da montagem do longa-metragem de Oliver Hirschbiegel, como a inserção de trechos documentais no início e no fim da obra. São dois trechos de depoimentos de Traudl Junge, ex-secretária de Hitler, colhidos pouco antes de sua morte. Essas inserções servem como uma espécie de "muro de contenção" narrativo onde, dentro dele, tudo pode ser encarado como um documento histórico, à maneira desses trechos documentais que o cercam, no início e no fim do longa.

Alguns "silêncios", para Caldas (2005), são reveladores. Exemplo é a omissão do cadáver do ditador que, após seu suicídio, não aparece em momento algum. Assim, a suposta tentativa do filme em humanizar Hitler cai por terra, ao negar ao espectador a visão da mortalidade do líder nazista.

O diretor do filme, em declarações sobre o filme, reforça a tentativa de fazer da trama uma reprodução fiel dos acontecimentos que precederam a derrocada nazista, ao fim da Segunda Guerra Mundial. Segundo ele, o roteiro do filme toma poucas liberdades em relação aos relatos dos personagens reais, como a secretária Traudl Junge, consignados em obras anteriores sobre o episódio. A atuação do ator Bruno Ganz como Adolf Hitler assegurou, por outro lado, a sensação de verossimilhança proposta pelo filme. Numa elogiada atuação, ele se destaca pela semelhança física com o líder supremo do nazismo.

\subsection{CENAS E CENOGRAFIAS}

Todo exemplar de gênero de discurso pressupõe um certo tipo de encenação do próprio ato discursivo, conforme defende Maingueneau (2008). Na prática, isso quer dizer que um texto (ou outro exemplar de gênero num regime semiótico ${ }^{10}$ diferenciado) se ancora em pertenças a determinadas cenas enunciativas, assim, como exibe uma determinada cenografia. Estruturadas em níveis, essas categorias subsumem certos papéis por parte de seus leitores/usuários. Assim, um anúncio de

${ }^{10}$ Por regime semiótico entendemos a forma de organização de uma ou mais matrizes ou modais semióticos (textos, imagens, sons) num exemplar de gênero qualquer. 
produto emagrecedor numa revista feminina atribui a seus leitores a posição de consumidores, mas também, mais especificamente, de leitores interessados em manter a forma, e, num terceiro momento, de interlocutores de uma personagem imaginária criada pelo anúncio.

$\mathrm{O}$ autor entende haver uma distinção entre uma cena englobante, que corresponde ao tipo de discurso - religioso, publicitário, político, entre outros - e uma cena genérica, que corresponde aos gêneros do discurso mobilizados pelos interlocutores. Finalmente, por cenografia entende-se a superfície do que se apresenta ao leitor numa determinada realização de um gênero. Alguns gêneros podem assumir diversas cenografias, ao passo que outros são menos sujeitos à adoção de registros cenográficos múltiplos. Para os efeitos deste artigo, intentamos localizar uma mudança de cena genérica ocorrida na migração de uma unidade de sentido originalmente pertencente ao gênero filme dramáticohistórico, que é retrabalhada para se tornar um exemplar do gênero paródia.

Aqui, cabe uma rápida consideração do mesmo autor acerca das condições em que ocorrem tais mudanças. Para Maingueneau (2008), mudanças no mídium em que um discurso é "transportado" podem acarretar mudanças de gênero. Assim, se imaginamos um filme cuja veiculação original ocorre no cinema migrando para outro mídium (a internet), é possível que se possa falar numa mudança de modos de codificação que impactam no enunciado, promovendo, assim, uma mudança de gênero.

\subsection{PRESSUPOSIÇÕES}

Pressupor é dizer algo além do que está enunciado numa dada expressão linguística. Não é preciso ser um estudioso da linguagem para saber que, quase todo o tempo, estamos projetando algo para além do sentido estável das palavras. Essa relação entre as sentenças e suas faces ocultas desperta o interesse de estudiosos da Linguística, da Lógica e da Filosofia da Linguagem. Fincando bandeira na fronteira entre esses campos, a Pragmática tem investigado como a linguagem é usada por seus falantes, ou melhor, como os enunciados se relacionam com os processos de interlocução (LEVINSON, 2007). 
Entre os fenômenos que passaram a despertar o interesse da Pragmática estão aqueles ligados ao contexto, que deixa de ser entendido apenas como guia para a localização de referentes numa frase e passa a ser encarado como tudo aquilo que é presumido pelos interlocutores (ARMENGAUD, 2006). A pressuposição é um desses casos. Inicialmente, a pressuposição foi definida por Frege (1952 [1892]) nos seguintes termos: sempre que se afirma algo, existe pressuposição óbvia de que os nomes próprios simples ou compostos que são utilizados têm denotação (referência). Já naquela época, Frege observou que tal denotação não faz parte do significado da sentença - o que poderia ser entendido como um primeiro passo em direção a uma ideia de pressuposição contextual (ou pragmática), como a conhecemos mais atualmente.

Strawson (1952) diz que uma pressuposição consiste no fato de que a verdade de um enunciado é uma pré-condição de verdade de um primeiro. Assim, dizer que "As lojas de Maria tiveram lucro neste ano" pressupõe que Maria é dona de lojas. No desenvolvimento do conceito, um avanço importante é trazido por Keenan (1971) ao diferenciar pressuposição lógica de pressuposição pragmática. Uma pressuposição lógica consiste no seguinte fato: uma sentença $S$ logicamente pressupõe uma sentença $\mathrm{S} 1$ no caso de $\mathrm{S}$ implicar $\mathrm{S} 1$ e a negação de $\mathrm{S}$, isto é, $\neg \mathrm{S}$, também implicar S1.

Já uma pressuposição pragmática é definida em função da relação entre o ato de enunciar uma sentença e o contexto no qual a enunciação ocorre. Assim, só é possível interpretar adequadamente uma ocorrência de pressuposição a partir do conhecimento compartilhado entre os falantes numa interação comunicativa. Atos de comunicação podem, assim, veicular intenções só recuperáveis a partir do entorno onde essa situação ocorre. Dizer que "está muito frio nesta sala" pode pressupor, por exemplo, um pedido para que o aparelho de ar-condicionado seja ajustado para uma temperatura maior.

Aqui, enxergamos o fenômeno das pressuposições para além dos limites das sentenças, ou seja, de maneira diferenciada em relação ao conceito adotado em estudos clássicos como os de Strawson (1952). Permitimo-nos expandir um pouco o conceito para flagrar pressuposições numa escala mais ampla, qual seja, a dos enunciados e 
suas bases de sustentação contextual. Assim, buscamos visualizar como os exemplares de vídeos analisados forçam Hitler a se agregar a uma cena enunciativa em que ele será, em alguma medida, ridicularizado, deslegitimado ou terá seu ethos esvaziado, para fins de obtenção de efeitos cômicos.

Assim, aproximamo-nos mais daquilo que Armengaud (2006) chamaria de pragmática de terceiro grau, pelo menos na convicção de que se pode adotar, como unidade mínima de análise dos atos comunicativos, a performance, e não simplesmente uma frase ou sentença. Se levarmos em conta as possibilidades que o conceito de pressuposição pragmática possui, como potencializador de intenções fora dos limites das sentenças de uma enunciação, poderíamos pensar em pressupostos que circulassem num circuito mais amplo, mobilizando o repertório sociocultural dos interlocutores para gerar efeitos de sentido.

\section{METODOLOGIA}

A geração dos dados analisados no artigo foi possibilitada por procedimentos que permitissem decodificar, num meio impresso, dados eminentemente visuais. O modelo de translação proposto por Rose (2002) surge como uma opção a partir da qual se pôde discernir os registros textual e visual de cada vídeo a ser analisado. A autora indica formas pelas quais podem ser descritos os aspectos visuais de produções em que as imagens em movimento lhes são constituintes. A autora prevê que, nesse processo, é impossível garantir que todas as nuances dos visuais sejam reproduzidas de uma maneira completamente fiel.

Dessa forma, cabe ao analista eleger critérios que lhe sirvam de lentes pelas quais o fenômeno pode ser enxergado. Não se trata de encobrir dados indesejáveis, mas sim de estabelecer parâmetros de análise que correspondam aos objetivos traçados pelo autor. Em vista disso, pretendemos identificar como o segmento visual dos vídeos, imutável ao longo dos exemplares analisados, norteia a construção textual das legendas, na medida em que estabelece um roteiro de emoções, de afetos, pelos quais Adolf Hitler e os demais personagens das cenas necessariamente precisam passar, ao longo do texto escrito. Como consequência, Hitler sai de um estado inicial silencioso, 
aparentemente controlado, para uma colérica reação às notícias dadas por seus aliados, sobre a iminente tomada de Berlim por tropas inimigas.

Mesmo que distante desse contexto histórico e dotada de outros propósitos, a legendagem fixa-se nas emoções encenadas e tenta adequar-se a elas, de forma a produzir um efeito de sentido (em outras palavras, um efeito dramático) minimamente compatível com aquele originalmente mostrado pelo filme.

O corpus analisado no artigo é composto por quatro exemplares de vídeos com cenas de $A$ Queda, em que o mesmo processo de legendagem foi realizado. Em todos os casos, foi realizada transcrição parcial de cada vídeo, conforme os procedimentos previstos por Rose (2002) e esclarecidos mais acima. Foi um primeiro passo para que pudéssemos isolar unidades de sentido capazes de mostrar como os vídeos registram certas pressuposições acerca da figura de Adolf Hitler e do regime nazista. Também propomos observar como acontecem as mudanças de cena enunciativa ocorridas na/pela mudança de mídium.

\section{RESULTADOS}

Berlim, abril de 1945. A Segunda Guerra Mundial se encaminha para um final. Os Aliados estão prestes a tomar Berlim e o exército alemão, encurralado no próprio país, parece sem saída. A Queda revela como foram os últimos dias de vida de Adolf Hitler, o líder nazista que insuflou o país, anos antes, com uma ideologia de supremacia e foi o responsável por um dos maiores genocídios da humanidade - seis milhões de judeus mortos em campos de concentração - em nome de um processo de limpeza étnica. Nesse contexto, como Hitler admitiria o declínio do chamado III Reich? A cena do filme escolhida para servir de base às legendagens paródicas realizadas por usuários do Youtube flagra, justamente, uma reação irada e desesperada de Hitler diante das notícias de que as tropas inimigas chegam em número suficiente para arrebatar Berlim, centro da resistência nazista.

O início do trecho parodiado pode variar conforme a reedição feita pelo usuário, mas, em geral, inicia-se com um dos militares da cúpula nazista indicando, em um mapa, os pontos críticos da investida aliada. Hitler busca minimizar a intensidade da situação, e recebe outras 
más notícias de seus subordinados. Até aqui contida, a cena adquire uma carga de intensidade dramática com um ímpeto furioso de Hitler, que se recusa a admitir a derrota e também responsabiliza seus subordinados. A língua alemã, pouco compreensível para parte considerável do público que acessa os vídeos no Youtube, parece facilitar as reedições por meio das legendas. A figura 2 mostra o processo de legendagem ao qual o filme é submetido.

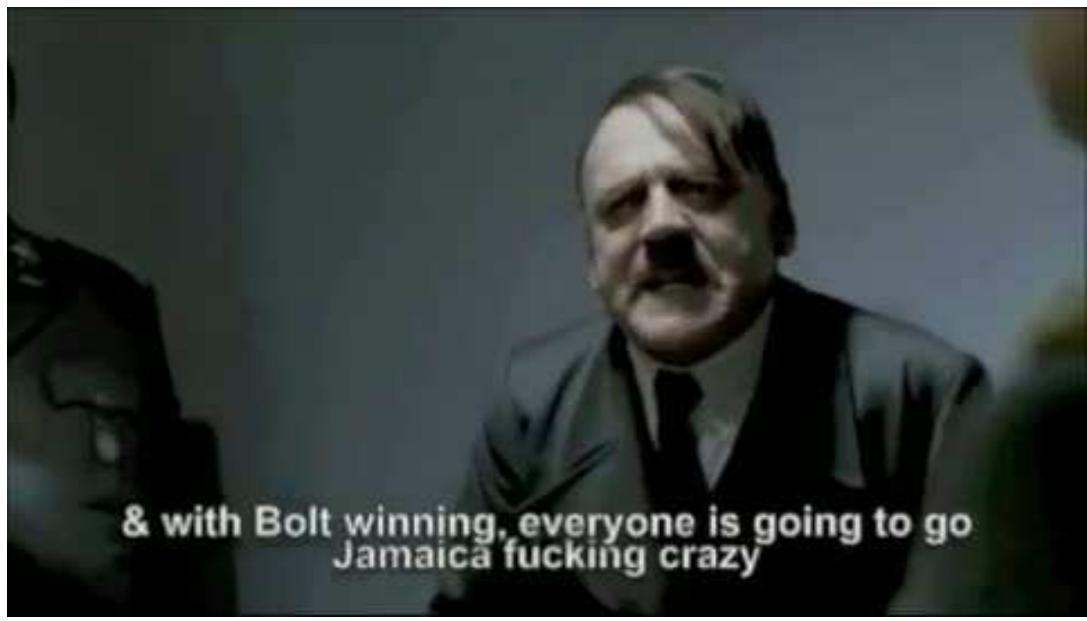

Figura 2 - Cena do filme $A$ Queda, postada no Youtube com legendagem paródica

A cena, portanto, dá margem para que haja a encenação de uma má notícia que provoca a fúria do líder. De posse dessa "espinha-dorsal" narrativa, os usuários-produtores podem adaptar a ela roteiros diversos, como a revolta de Hitler por ver o regime nazista comparado à Uniban (universidade na qual a estudante Geisy Arruda foi hostilizada por ir à aula trajando um vestido curto). A cena escolhida, e reproduzida em todos os vídeos por nós obtidos, é elucidativa do quanto Hitler, antes de tudo, parece ser o último a saber sobre certos assuntos. As "notícias" sobre o caso Uniban são dadas pelos imediatos.

Os vídeos analisados mostram, de forma geral, as seguintes situações: 


\section{Vídeo 1 - A Queda da Uniban}

Hitler comenta o caso da estudante Geisy Arruda, que fora hostilizada nas dependências da faculdade Uniban, em São Paulo, por usar roupas consideradas inapropriadas. Ele se enfurece quando sabe que a Uniban está sendo comparada ao regime nazista;

\section{Vídeo 2 - Sem Twitter para Hitler}

Hitler é informado da saída do ar do servidor responsável pelo microblog Twitter e se enfurece por não poder noticiar, para seus seguidores, a morte de sua cachorrinha Blondie.

\section{Vídeo 3 - Usain Bolt quebra o recorde dos 100 metros e Hitler reage}

Aqui, Hitler vai se confrontar com um "trauma do passado", as Olimpíadas de Munique, em 1938, quando o americano (e negro) Jesse Owens venceu a prova dos 100 metros. Hitler é informado de que o jamaicano Usain Bolt não apenas venceu a prova (nos Jogos de Pequim) como também bateu o recorde mundial.

\section{Vídeo 4 - Hitler odeia os Jonas Brothers}

Hitler fica sabendo do sucesso obtido pelo grupo americano Jonas Brothers. Em seguida, como se os fatos fossem concomitantes, reage chocado ao fato de que os Beatles se separaram. É o mote para que ele diga impropérios direcionados aos Jonas Brothers.

No filme original, a cena ocorre ainda no primeiro terço do filme, por volta de 37 minutos (o filme tem 156 minutos no total). Berlim está sob ataque aliado e Hitler é informado de que o inimigo realizou uma invasão, tomando Zossen e se encaminhando para Stahnsdorf. Os aliados localizam-se, àquela altura, na fronteira norte e leste da cidade. Hitler afirma que, com o ataque de Steiner (o comandante responsável por um ataque-surpresa planejado por ele), "tudo ficará bem". Seus subordinados objetam que Steiner e sua tropa não tiveram força suficiente e o ataque não aconteceu. Nesse momento, Hitler enfurece-se e afirma que o ataque era uma ordem que não poderia ser desobedecida. Reclama que os militares e mesmo a SS (esquadrão de elite do exército alemão) mentiram para ele. O Führer segue afirmando que os generais são um bando de covardes desleais. Um dos militares tenta objetar, sem sucesso. A discussão segue, com Hitler questionando a formação dos 
generais nas academias militares. Hitler sugere ainda que todo o alto escalão de generais seja morto, como Stalin fez. "Nunca fui à academia, mas conquistei a Europa sozinho", diz. Mais adiante, diz que a "a guerra está perdida", mas promete não deixar Berlim.

Em A Queda, essa cena desempenha papel crucial no filme. Ali, Hitler percebe que a guerra não poderia mais ser vencida. É quando a resistência nazista se desorganiza e Hitler planeja e executa seu suicídio, junto com a amante Eva Braun.

Nos vídeos escolhidos para a realização deste trabalho, evidenciase, num primeiro momento, a adaptação de uma cena enunciativa cinematográfica. Nessa cena, o público-alvo é interpelado como um espectador de cinema interessado em acompanhar a reconstituição de fatos históricos. Em tal cena, o filme pode ser avaliado por críticos especializados, de acordo com certos parâmetros. Após a captura da cena, acréscimo de legendagem e postagem no Youtube ou outro canal de vídeo, o tipo de discurso se modifica, e por tabela, a cena englobante. Aqui, o público-alvo passa a ser interpelado como dono de um repertório intertextual capaz de fazê-lo captar as referências e implícitos contidos numa paródia, que retira Hitler de seu lugar original e o recoloca como um comentarista, um tanto deslocado e radical, de acontecimentos dos dias atuais.

A outra mudança a que se submete o filme, nessa migração, é de ordem genérica. Além do tipo do discurso sofrer alteração, o gênero também passa a ser outro. Se considerarmos os propósitos de cada uma das modalidades de produção (cf. SWALES, 1990), entenderemos que o filme original tem pretensões de se encenar como documento histórico (como já se disse anteriormente), que se contrapõe a um fim de comentário social contemporâneo, realizado por meio da temida figura de Hitler, que é, inicialmente, recontextualizada num tempo-espaço diferente do original. Ele também é deslegitimado por suas posições irredutíveis e ridicularizado pela lentidão com que toma conhecimento de certos fatos.

A coincidência entre $A$ Queda e suas paródias na internet parece residir na cenografia utilizada por ambos para atingirem seus propósitos. No fim das contas, ambas as realizações genéricas se dão por meio de uma cenografia comum: um trecho audiovisual, que se passa num bunker 
nazista em 1945, com narrativa linear, atores contracenando e o uso de legendas para tradução de diálogos na língua alemã. Da mesma maneira que o filme original pode ser acompanhado em sites como o Youtube (bem como, obviamente, em outras mídias como o DVD), suas paródias também encontram nesse site seu ambiente de reprodução e replicação.

A manutenção da cenografia é que parece ter permitido, ao longo do tempo, a caracterização do conjunto de paródias como um fenômeno viral. Embora mudem as legendas, as imagens utilizadas são invariavelmente as mesmas. $\mathrm{Na}$ figura 3 , esquematizamos o conjunto de mudanças ocorridas no processo de transformação de $A$ Queda numa paródia.

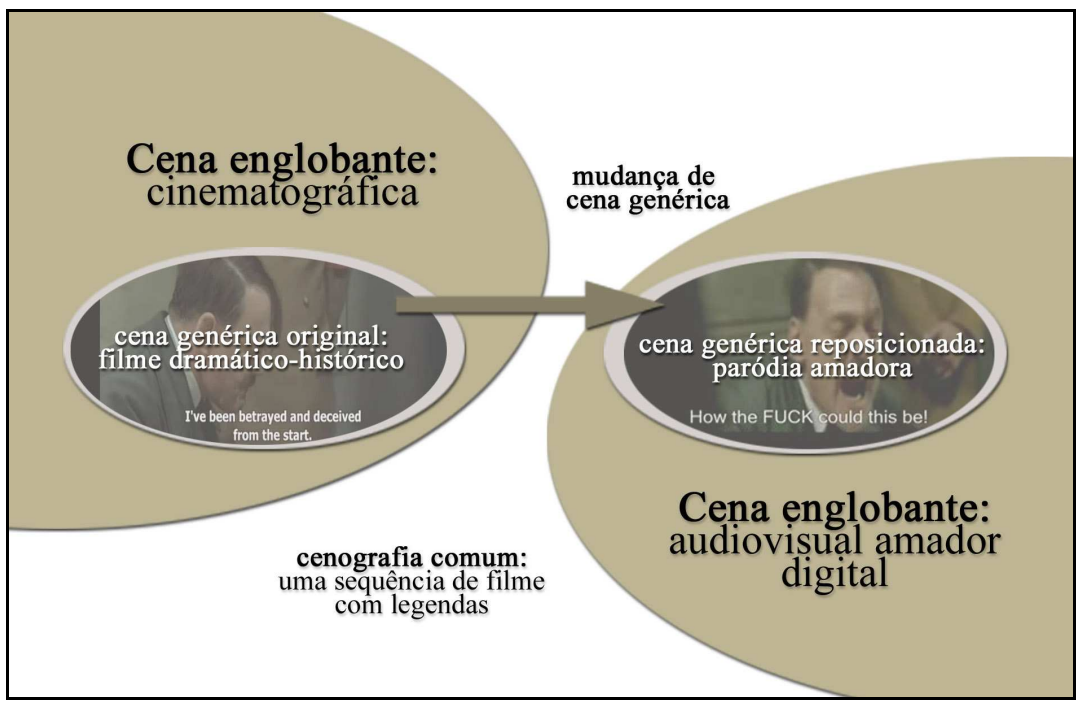

Figura 3 - Migração entre cenas englobantes e genéricas, de acordo com a classificação de Maingueneau (2008)

Nessa mudança de cenas, algumas estratégias argumentativas emergem, para materializar os pretensos propósitos dos produtores das paródias. Elas fazem, necessariamente, referência a um contexto que não é mais o da Alemanha tomada pelo nazismo. O tipo de registro textual trazido pelas legendas também demarca uma mudança de cena, de época 
e de modos: há o uso de palavrões, gírias não existentes na época em que os fatos mostrados ocorreram. A finalidade maior parece ser a de ironizar o regime nazista ou, em outras palavras, aproximar Hitler de cenas capazes de evidenciar seu extremismo e descontrole. Ao fazer isso, os produtores dos vídeos parecem deslegitimá-lo perante os interlocutores. As pressuposições atuariam para ancorar tal tipo de leitura.

Nos quadros das páginas seguintes, apresentamos algumas pressuposições que podem ser inferidas em cada um dos vídeos analisados (a transcrição deles encontra-se no Anexo deste trabalho). Em todos eles, uma pressuposição de base guia a recepção dos vídeos: a de que Hitler assume a posição de uma entidade atemporal, capaz de reagir a fatos ocorridos em pleno século 21. Como dito anteriormente, especulamos sobre pressuposições para além dos limites das sentenças, buscando perceber como essas relações podem ser dar, também, ao nível das enunciações.

Ao longo da análise, parece consensual que, em todos os casos, as pressuposições que se podem depreender dos diálogos e dos modos de Hitler (a fúria do personagem é potencializada pela atuação de Bruno Ganz no papel) são invariavelmente jocosas e frequentemente remetem aos piores aspectos do nazismo, como a intolerância em relação às minorias. Em alguns casos, esses aspectos são pressupostos com fina ironia, como quando Hitler expressa preocupação fora do normal com a repercussão do caso Uniban, o que poderia ameaçar a imagem dos nazistas como "campeões de intolerância".

O corpus analisado contribui, em nosso entendimento, para confirmar posicionamentos como o defendido por Keenan (1971) e Levinson (2007) a respeito da existência das chamadas pressuposições pragmáticas. Nesse sentido, as pressuposições que constituem o "fundo" subjacente à "figura", isto é, os enunciados efetivamente realizados, apresentam, como condição de sua interpretação e alcance, o contexto de enunciação e o repertório partilhado pelos interlocutores.

Ao se lançar uma visão geral para os vídeos analisados, percebe-se como a dimensão contextual é evidenciada, pois é nela que as diversas referências contemporâneas elencadas no vídeo se estabelecem e formam unidades portadoras de sentido. É no contexto que podemos realizar a 
ligação entre Usain Bolt e Jesse Owens, em um dos vídeos, ou, em outro caso, compreender como uma ironia a expressão "sujar o bom nome do nazismo". Ao outorgar ao público-alvo a tarefa de mobilizar tais referências e adequá-las a uma ideia preexistente do que foi o nazismo, os autores dos vídeos acabam por demarcar a originalidade dessas produções típicas da web 2.0.

\begin{tabular}{|c|c|}
\hline \multicolumn{2}{|l|}{ Vídeo 1 - A Queda da Uniban } \\
\hline SITUAÇÃO ENCENADA & PRESSUPOSIÇÃO \\
\hline $\begin{array}{l}\text { Hitler é informado de que a } \\
\text { Uniban, após a expulsão de } \\
\text { Geisy Arruda, está sendo } \\
\text { comparada aos nazistas. Ele } \\
\text { reage dizendo: } \\
\text { Eu não aceito isso! Nós temos } \\
\text { critérios, temos padrões! O que deu } \\
\text { na cabeça desse pessoal! Quem são } \\
\text { esses alunos da Uniban? Um bando } \\
\text { de mauricinhos e barangas invejosas! }\end{array}$ & $\begin{array}{l}\text { O nazismo jamais poderá ser comparado a um agrupamento de } \\
\text { estudantes hostis de uma faculdade brasileira. O modus operandi } \\
\text { nazista é muito mais eficiente, em suas maldades. Haveria uma } \\
\text { espécie de "parâmetro de qualidade" a partir do qual poder-se-ia } \\
\text { diferenciar o nazismo da Uniban. }\end{array}$ \\
\hline $\begin{array}{l}\text { Hitler diz: Eu trabalhando duro } \\
\text { para criar um Reich que vai durar } \\
\text { mil anos. Ai vem essa faculdade e } \\
\text { quer sujar o bom nome do nazismo? }\end{array}$ & $\begin{array}{l}\text { Hitler é um trabalhador a serviço de um projeto sólido, } \\
\text { duradouro, o III Reich. O nazismo, por sua vez, é uma causa } \\
\text { com um bom nome, ameaçado pela Uniban após o caso Geisy. } \\
\text { Note-se que a repercussão das atitudes da Uniban com relação } \\
\text { ao caso (a expulsão da aluna, as alegações usadas para tanto) foi } \\
\text { negativa, o que justificou a fama "nazista" atribuída à faculdade. }\end{array}$ \\
\hline $\begin{array}{l}\text { Hitler diz: Não interessa! Nós } \\
\text { somos os campeões de preconceito e } \\
\text { intolerancia, cacete! }\end{array}$ & $\begin{array}{l}\text { Aqui, Hitler mais uma vez assume uma postura competitiva em } \\
\text { relação ao que considera uma questão de honra do nazismo: o } \\
\text { desempenho eficiente na propagação de "preconceito e } \\
\text { intolerância", ameaçado pelo caso Uniban. }\end{array}$ \\
\hline $\begin{array}{l}\text { Hitler diz: Tanta coisa pra ser } \\
\text { intolerante... por que não os judeus? }\end{array}$ & $\begin{array}{l}\text { Aqui, o foco desvia para a real história nazista, com um histórico } \\
\text { de intolerância a judeus que resultou num dos maiores } \\
\text { genocídios já registrados. Hitler afirma a "seletividade" do ódio } \\
\text { nazista, ao condenar a Uniban por discriminar uma mulher por } \\
\text { usar uma roupa curta. Para Hitler, gays e judeus seriam um } \\
\text { melhor objeto de execração. }\end{array}$ \\
\hline \multicolumn{2}{|c|}{$\begin{array}{l}\text { Nessa cena, parece residir o pressuposto mais geral de que Hitler é um competitivo "empresário" a } \\
\text { serviço de maldades em larga escala, ameaçado pela "concorrência" aqui representada por alunos e } \\
\text { direção da faculdade Uniban. É um primeiro exemplo daquilo que chamamos de pressuposição } \\
\text { pragmática, isto é, guiada pelo contexto. Isso ocorre na medida em que se exige do espectador do } \\
\text { vídeo, em alguma medida, que ele possua em seu repertório conhecimentos mínimos sobre Hitler, o } \\
\text { III Reich e a perseguição a judeus. }\end{array}$} \\
\hline
\end{tabular}

Quadro 1 - Pressuposições inferíveis a partir do vídeo 1 do corpus 


\begin{tabular}{|c|c|}
\hline \multicolumn{2}{|l|}{ Vídeo 2 - Sem Twitter para Hitler } \\
\hline SITUAÇÃO ENCENADA & PRESSUPOSIÇÃO \\
\hline \multirow[t]{2}{*}{$\begin{array}{l}\text { Hitler é informado de que sua } \\
\text { cachorrinha Blondie (ou Loura, em } \\
\text { português) é atropelada nos arredores } \\
\text { de Berlim e não resiste. Hitler reage } \\
\text { afirmando que amava o animal e } \\
\text { precisa, imediatamente, reportar o } \\
\text { fato em seu perfil no microblog } \\
\text { Twitter. }\end{array}$} & $\begin{array}{l}\text { Hitler é um personagem presente nas redes sociais como o } \\
\text { Twitter e, como muitos dos usuários, sente a necessidade - } \\
\text { à beira do patológico - de atualizar seu microblog com } \\
\text { eventos que considere relevantes. Tal necessidade suplanta } \\
\text { o próprio sentimento que ele nutria pelo cão. Assim, Hitler } \\
\text { parece mais preocupado em publicizar o ocorrido do que } \\
\text { realmente lamentar a perda. }\end{array}$ \\
\hline & $\begin{array}{l}\text { Alem das pressuposi } \\
\text { (GRICE, 1975) a pa } \\
\text { Hitler". Blondie, ou } \\
\text { ariana propagado pel }\end{array}$ \\
\hline $\begin{array}{l}\text { Hitler diz: Tenho mais de dois mil } \\
\text { seguidores que precisam saber cada detalhe } \\
\text { da minha vida! De que outro modo eu } \\
\text { poderei comunicar minha tristeza a tanta } \\
\text { gente simultaneamente! }\end{array}$ & $\begin{array}{l}\text { momentos marcantes } \\
\text { cineasta Leni Riefens } \\
\text { parece crente na nece } \\
\text { também para eventos } \\
\text { Hitler se direciona aos } \\
\text { o serviço de microblog }\end{array}$ \\
\hline $\begin{array}{l}\text { [Militar 3] Porque não dar ao Tumblr }{ }^{11} \\
\text { uma chance? } \\
\text { [Hitler] Tumblr? Eu pareço estar usando } \\
\text { um vestido? }\end{array}$ & $\begin{array}{l}\text { reage afirmando que o Tumblr é coisa } \\
\text { ressurge um Hitler radical, revelando } \\
\text { relação à questão de gênero. Ele teme } \\
\text { uma garota. Como mostra o própri } \\
\text { nazismo era um regime cujo comand } \\
\text { masculino. As mulheres cumpriam }\end{array}$ \\
\hline $\begin{array}{l}\text { Hitler diz: Eu poderia falar com pessoas } \\
\text { na vida real, então. Você sabe o quão } \\
\text { cansativo é isso? }\end{array}$ & $\begin{array}{l}\text { Não por acaso, preso em um bunker, Hitler assinala ser } \\
\text { mais fácil (ou menos cansativo) se relacionar com pessoas } \\
\text { à distância, em redes sociais. A frase parece aludir à própria } \\
\text { condição de Hitler, num determinado momento da } \\
\text { história, como líder isolado do restante do mundo. }\end{array}$ \\
\hline \multicolumn{2}{|c|}{$\begin{array}{l}\text { Aqui, a pressuposição mais geral parece apontar para a crença de que as redes sociais podem tornar- } \\
\text { se um passatempo doentio. Mesmo Hitler sucumbe a tal poder e, previsivelmente, reage } \\
\text { furiosamente quando informado da inoperância do serviço. A dependência de Hitler às redes sociais } \\
\text { parece metaforizar, de alguma maneira, o isolamento que ele se impôs (ou foi obrigado a seguir) no } \\
\text { período mais crítico do nazismo. Mais uma vez, as legendas são o gatilho para o acionamento de } \\
\text { pressuposições que se localizam além das sentenças, mais especificamente em conteúdos } \\
\text { proposicionais que não estão claramente comunicados, conduzindo-nos àquilo que Armengaud } \\
\text { (2006) identifica como condição básica da interpretação das pressuposições: o conhecimento } \\
\text { partilhado pelos interlocutores. }\end{array}$} \\
\hline
\end{tabular}

Quadro 2 - Pressuposições inferíveis a partir do vídeo 2 do corpus

${ }^{11}$ Outra plataforma de publicação de microblog.

ARAÚJO; COSTA - A fúria do Führer... 


\begin{tabular}{|c|c|}
\hline $\begin{array}{l}\text { SITUAÇÃO } \\
\text { ENCENADA }\end{array}$ & PRESSUPOSIÇÃO \\
\hline $\begin{array}{l}\text { Hitler diz: Eu não } \\
\text { poderia aguentar outro } \\
\text { homem negro } \\
\text { bumilhando em } \\
\text { próprio país como Jessie } \\
\text { Owens. }\end{array}$ & $\begin{array}{l}\text { A legenda traz à tona um contexto histórico que nos remete às } \\
\text { Olimpíadas de Berlim, em 1936, quando Jesse Owens ganhou três } \\
\text { medalhas de ouro, uma delas (salto em distância) vencendo um atleta } \\
\text { alemão. Hitler é imaginariamente confrontado com uma situação } \\
\text { parecida: outro atleta negro, o jamaicano Usain Bolt, recém-recordista, } \\
\text { em } 2008 \text {, dos } 100 \text { metros mundiais, com a marca de } 9,58 \text { segundos. O } \\
\text { detalhe é que a conquista também aconteceu em Berlim, como ocorrera } \\
72 \text { anos antes. Hitler "vive" para presenciar a segunda "humilhação", o } \\
\text { que obviamente aponta para o preconceito racial que permeia a doutrina } \\
\text { nazista. Hitler, aqui, parece atemorizado pela perspectiva da repetição de } \\
\text { 1936, o que parece uma desonra. A pressuposição é a de que, mesmo no } \\
\text { século XXI, é intolerável o triunfo de um negro, sobretudo em território } \\
\text { alemão. }\end{array}$ \\
\hline $\begin{array}{l}\text { [Militar 2] Usain Bolt } \\
\text { quebrou o recorde dos } 100 \\
\text { metros hoje. Ele terminou a } \\
\text { prova com } 9.58 \text { segundos. } \\
\text { [Hitler pensativo. Tira } \\
\text { os óculos com mão } \\
\text { trêmula] } \\
\text { [Hitler] Todos os que } \\
\text { gostam daquela droga de } \\
\text { filme Jamaica Abaixo de } \\
\text { Zero [Cool Runnings] } \\
\text { saiam agora. }\end{array}$ & $\begin{array}{l}\text { Ao aludir ao filme Jamaica Abaixo de Zero, Hitler parece expressar o senso } \\
\text { comum a partir do qual a Jamaica é compreendida no restante do mundo. } \\
\text { O filme trata de uma equipe jamaicana de trenó que triunfa nos Jogos } \\
\text { Olímpicos de inverno. Seria a única referência de sucesso jamaicano no } \\
\text { esporte, e é mencionada por Hitler para demarcar o espaço de suas } \\
\text { reflexões sobre Usain Bolt. Aqueles que gostam da "droga de filme" } \\
\text { certamente celebrariam a vitória de Bolt. A mesma lógica rege as demais } \\
\text { citações de artistas jamaicanos realizadas por Hitler ao longo do vídeo. }\end{array}$ \\
\hline \multicolumn{2}{|c|}{$\begin{array}{l}\text { A imagem de Hitler projetada ou pressuposta a partir deste vídeo é de alguém cujos preconceitos } \\
\text { raciais chegam ao limite do ódio irracional. Ao aludir a um fato realmente ocorrido, o produtor deste } \\
\text { vídeo parece querer trazer um Hitler mais próximo do real, ainda que outras referências sejam } \\
\text { evidentemente deslocadas temporalmente e produzam efeito caricatural (caso da referência a } \\
\text { cantores como Sean Paul). Aqui, as cenas enunciativas produtoras, por um lado, de um Hitler } \\
\text { "realista" e, de outro, de um Hitler caricatural, parecem se aproximar. O vídeo parece pressupor } \\
\text { como Hitler reagiria se estivesse vivo no século } 21 \text { ao ver a vitória de Usain Bolt. }\end{array}$} \\
\hline
\end{tabular}

Quadro 3 - Pressuposições inferíveis a partir do vídeo 3 do corpus 


\begin{tabular}{|c|c|}
\hline \multicolumn{2}{|c|}{ Vídeo 4 - Hitler odeia os Jonas Brothers } \\
\hline SITUAÇÃO ENCENADA & PRESSUPOSIÇÃO \\
\hline $\begin{array}{l}\text { Diálogo: } \\
\text { [Hitler] Não se preocupe eu vou } \\
\text { ver os Beatles amanhã. } \\
\text { [Militares se entreolham] } \\
\text { [Militar 1] Meu Fubrer... Os... } \\
\text { [Militar 2] Os Beatles } \\
\text { terminaram. Não sabemos por } \\
\text { quê. Eles dizem que os Jonas } \\
\text { Brothers são os próximos Beatles. }\end{array}$ & $\begin{array}{l}\text { O autor das legendas joga com o repertório musical desse Hitler } \\
\text { "contemporâneo". Ao mesmo tempo em que ele desconhece o fim } \\
\text { dos Beatles (a banda se separou em 1970), ele tem uma opinião } \\
\text { formada sobre os Jonas Brothers. Nem os próprios militares } \\
\text { nazistas sabem a razão da separação dos Beatles. O diálogo serve } \\
\text { de pretexto para que Hitler, uma vez informado do fim dos } \\
\text { Beatles, direcione sua decepção para a banda sensação do } \\
\text { momento, os Jonas Brothers. Assim, o Hitler aqui mostrado não } \\
\text { parece ter maturidade suficiente para lidar com uma "perda" sem } \\
\text { que para isso tenha de culpar, de certa forma, outros artistas. }\end{array}$ \\
\hline $\begin{array}{l}\text { Diálogo: } \\
\text { [Militar 3] Meu Senhor, nós } \\
\text { temos os Jonas Brothers! Como } \\
\text { alguém já disse! } \\
\text { [Hitler] Os Jonas Brothers! Estão } \\
\text { mais para os "Jonas Sisters"! } \\
\text { Quero quebrar seu pescoço! } \\
\text { [Hitler. De pé] Se eu quiser } \\
\text { ouvir os deuses cantarem, eu ouço } \\
\text { os Beatles. Mas se eu quiser owvir } \\
\text { bichas que não atingiram a } \\
\text { puberdade então eu escolho os } \\
\text { Jonas Brothers, e eu não quero } \\
\text { ouvir esse lixo! }\end{array}$ & $\begin{array}{l}\text { Nesses trechos, Hitler compara os Jonas Brothers a garotas, seja } \\
\text { chamando-os de Jonas Sisters ou afirmando que eles são "bichas que } \\
\text { não atingiram a puberdade". Os Jonas Brothers, americanos, } \\
\text { parecem canalizar a revolta de Hitler em relação a todo tipo de } \\
\text { música para adolescentes contemporânea. Hitler é presentificado } \\
\text { como um conservador, em termos de música. Porém, esse homem } \\
\text { mostra-se um tanto confuso por não saber sequer que seus ídolos, } \\
\text { os Beatles, haviam terminado. O status "gay", aqui, ganha } \\
\text { dimensão de ofensa. }\end{array}$ \\
\hline \multicolumn{2}{|c|}{$\begin{array}{l}\text { A plasticidade com que a figura de Hitler é moldada ao longo dos vídeos ganha aqui mais uma } \\
\text { manifestação, em que subjaz mais uma tentativa de ridicularização do líder nazista. Pode-se louvar o } \\
\text { bom gosto musical de Hitler (os Beatles são uma preferência universal), no entanto não se poderia } \\
\text { dizer o mesmo de sua extremada reação à simples aproximação dos Jonas Brothers de Berlim, como } \\
\text { mostra o início da transcrição deste vídeo. O desconhecimento de Hitler acerca do fim dos Beatles } \\
\text { acentua a caricatura do líder que se depreende dessa legendagem. }\end{array}$} \\
\hline
\end{tabular}

Quadro 4 - Pressuposições inferíveis a partir do vídeo 4 do corpus 


\section{CONSIDERAÇÕES FINAIS}

As cenas podem provocar risadas. São caricaturas de uma respeitável figura histórica, afinal de contas. O idioma alemão parece contribuir para o efeito cômico. As impressões vão se acumulando. Assim foram os primeiros contatos com os vídeos que integram o "fenômeno viral Hitler", no site de compartilhamento de vídeos Youtube. A partir dessa primeira visão, buscou-se ir um passo além do evidente efeito cômico-paródico sugerido pelo conjunto de vídeos - uma das maneiras que os usuários-produtores da web 2.0 encontraram para expressar certas opiniões. Caminhou-se em direção a uma moldura teórica capaz de enquadrar (ou capturar) o componente contextual acionado sempre que se aperta o botão play de uma dessas produções.

Optamos por tentar atualizar algumas ideias das teorias sobre pressuposição (e, num breve relance, sobre a implicatura griceana) de forma a fazê-las abraçar esse objeto surgido do fértil terreno dos gêneros emergentes, capazes de atualizar (ou transmutar) gêneros preexistentes. Aqui, observamos como esses processos aliam-se a uma certa dose de transgressão, para desconstruir figuras históricas como a de Adolf Hitler, objeto de chacota em vídeos que se multiplicam e servem à repercussão de assuntos diversos.

$\mathrm{Na}$ análise, buscamos identificar que pressuposições subjaziam a determinadas passagens dos vídeos e, num segundo momento, aos vídeos como um todo. Invariavelmente, Adolf Hitler se excede ao comentar fatos como o "caso Geisy Arruda" ou as constantes falhas técnicas do site Twitter. Em maior ou menor medida, a materialização da figura de Hitler em cenas enunciativas tão diversas quanto distantes da história nazista parecem convergir para o reposicionamento de Hitler como um comentarista equivocado e reacionário dessas cenas.

Obviamente, outras modalidades de análise seriam possíveis para o objeto escolhido. No campo da Pragmática, seria possível explorar as implicações dos diálogos presentes nos vídeos, ou ainda verificar se tais vídeos poderiam ser considerados atos de fala. Uma análise sob o prisma dos gêneros do discurso também seria possível. Essas são sugestões de continuidade para o presente trabalho. 


\section{REFERÊNCIAS}

ARAÚJO, J. C. A conversa na web: o estudo da transmutação em um gênero digital. In: MARCUSCHI, L. A.; XAVIER, A. C. (Org.). Hipertexto e gêneros digitais: novas formas de construção de sentidos. 2. ed. Rio de Janeiro: Lucerna, 2004. p. 91-109.

. Os chats: uma constelação de gêneros na Internet. 2006. 341f. Tese (Doutorado em Linguística). Programa de Pós-graduação em Linguística, Universidade Federal do Ceará, Fortaleza, 2006.

ARMENGAUD, F. Pragmática. São Paulo: Parábola Editorial, 2006.

ASKWITH, I. Television 2.0: Reconceptualizing TV as an engagement medium. 2007. 174f. Tese (Master of Science in Comparative Media Studies). Massachussets: MIT, 2007.

BAKHTIN, M., Os gêneros do discurso. In: verbal, São Paulo: Martins Fontes, [1979] 2000, p. 278-326.

CALDAS, P. S. P. A câmera como bunker: o filme $A$ Queda e o problema da consciência histórica alemã. Fênix - Revista de História e Estudos

Culturais, v. 2, n. 4, out./nov./dez. 2005.

DEODATO, Lívia. O efeito viral de Hitler. Revista Época. Rio de Janeiro, 11 set. 2009.

FREGE, G. On sense and reference. In: GEACH, P. T.; BLACK, M. (Orgs.) Translations from the philosphical writings of Gottlob Frege. Oxford: Blackwell, 1952.

GRICE, H. P. Logic and conversation. In: COLE, P.; MORGAN, J. L. (orgs.) Syntax and Semantics 3: Speech Arts. Nova York: Academic Press, 1975.

HELM, S. Viral Marketing - Establishing customer relationships by "Word-ofmouse". Electronic Markets, v. 10, n.3, p. 158-161, 2000.

JENKINS, H. Cultura da convergência. São Paulo: Editora Aleph, 2008.

KEENAN, E. L. Two kinds of pressuposition in natural language. In: FILLMORE, C. J.; LANGENDOEN, D. T. (Orgs.) Studies in Linguistics Semantics. Nova York: Holt, 1971.

LEMKE, J. L. Travels in hypermodality. London, Thousand Oaks, CA, New Delhi: SAGE Publications, Vol. 1, 2002, p. 299-325. 
LEVINSON, S. C. Pragmática. São Paulo: Martins Fontes, 2007.

MAINGUENEAU, D. Análise de textos de comunicação. São Paulo: Cortez, 2008.

MARCUSCHI, L. A.; XAVIER, A. C. (Orgs.). Hipertexto e gêneros digitais. Rio de Janeiro: Lucerna, 2004.

O'REILLY, T. What is Web 2.0. O'REILLY, 2005. Disponível em:

$<$ http://oreilly.com/web2/archive/what-is-web-20.html>. Acesso em: 30 jun. 2009.

ROSE, D. Análise de imagens em movimento. In: GASKELL, G.; BAUER, M. W. Pesquisa qualitativa com texto, imagem e som: um manual prático. Petrópolis: Vozes, 2002, p. 343-364.

STRAWSON, P. F. Introduction to logical theory. Londres: Methuen, 1952.

SWALES, John M. Genre analysis: English in academic and research settings. Cambridge: Cambridge University Press, 1990.

TROSBORG, A. (Ed.) Analysing professional genres. Amsterdam: John Benjamins, 2000.

ZAVAM, A. S. Por uma abordagem diacrônica dos gêneros do discurso à luz da concepção de tradição discursiva: um estudo com editoriais de jornal. 2009. 420f. Tese (Doutorado em Linguística)-Programa de Pós-graduação em Linguística, Universidade Federal do Ceará, Fortaleza, 2009.

\section{ANEXO - TRANSCRIÇÕES DE VÍDEOS}

Em todas as transcrições, optou-se por reproduzir os diálogos na coluna de vídeo, e não na de áudio, por se tratar de legendas incluídas $a$ posteriori, e ausentes do original (filme $A$ Queda). Na coluna de áudio, registra-se o fato de que o áudio original, em alemão, foi mantido. 


\section{Vídeo 1 - A Queda da Uniban}

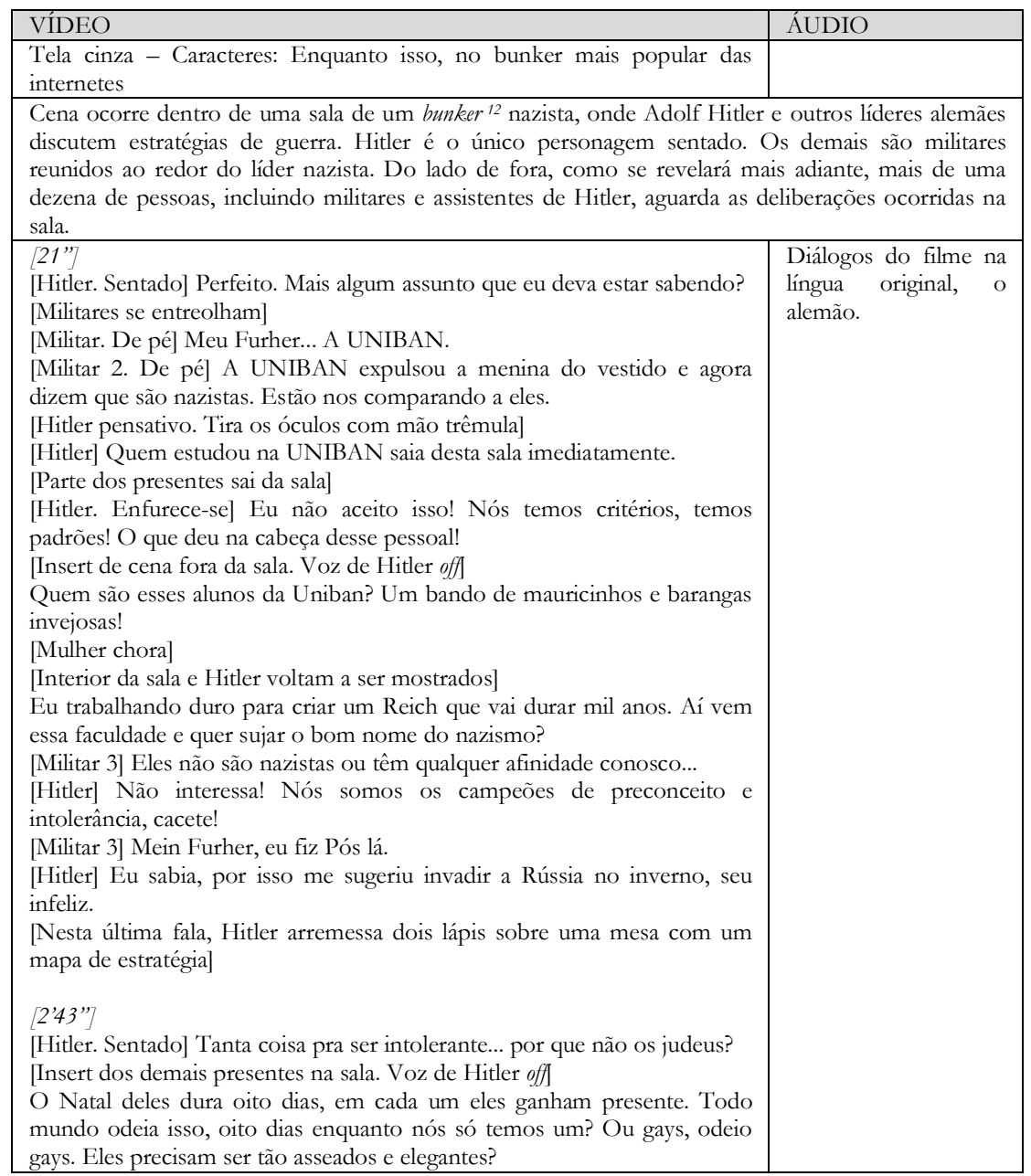

${ }^{12}$ Casamatas, ou fortificações militares que dão guarida a exércitos durante confrontos.

ARAÚJO; COSTA - A fúria do Führer... 


\section{Vídeo 2 - No Twitter for Hitler (Sem Twitter para Hitler) ${ }^{13}$}

\begin{tabular}{|c|c|}
\hline \multirow{2}{*}{\multicolumn{2}{|c|}{\begin{tabular}{l|l} 
VÍDEO & ÁUDIO \\
Cena ocorre dentro de uma sala de um bunker nazista, onde Adolf Hitler e outros líderes alemães \\
discutem estratégias de guerra. Hitler é o único personagem sentado. Os demais são militares \\
reunidos ao redor do líder nazista. Do lado de fora, como se revelará mais adiante, mais de uma \\
dezena de pessoas, incluindo militares e assistentes de Hitler, aguarda as deliberações ocorridas na \\
sala.
\end{tabular}}} \\
\hline & \\
\hline $\begin{array}{l}\text { [4’] } \\
\text { [Militar 1] Sua cachorra Blondie (Loira) foi atropelada por um carro nesta } \\
\text { manhã. Ela estava brincando nas ruas fora dos limites de Berlim. O } \\
\text { responsável fugiu em seguida, então ninguém sabe quem fez isso. Ela foi } \\
\text { levada para um hospital, mas era muito tarde. Sinto muito, senhor. } \\
\text { [Hitler] Sabe, eu amava aquela cachorra. Preciso tuitar (tweet) isso. } \\
\text { [Militares se entreolham] } \\
\text { [Militar 1] Senhor Hitler... Twitter... } \\
\text { [Militar 2] Twitter está fora do ar desde a noite passada. Aparentemente Robert } \\
\text { Scobble14 sobrecarregou os servidores. } \\
\text { [Hitler pensativo. Tira os óculos com mão trêmula] } \\
\text { [Hitler] Todos os que se acham legais (cool) demais para usarem Twitter podem } \\
\text { sair. } \\
\text { [Parte dos presentes sai da sala] } \\
\text { [Hitler. Enfurece-se] Não acredito que está fora do ar novamente! Todo santo } \\
\text { dia está fora do ar! Eles não acabaram de receber } 15 \text { milhões em fundos de } \\
\text { capital de risco (VC funding)? } \\
\text { [Insert de cena fora da sala. Voz de Hitler off } \\
\text { Eles não se importam com seus usuários? Eles não se importam conosco, os } \\
\text { Tweeple15? } \\
\text { [Mulher chora] } \\
\text { [Interior da sala e Hitler voltam a ser mostrados] } \\
\text { Tenho mais de dois mil seguidores que precisam saber cada detalhe da minha } \\
\text { vida! De que outro modo eu poderei comunicar minha tristeza a tanta gente } \\
\text { simultaneamente! } \\
\text { [Militar 3] Porque não dar ao Tumblr16 uma chance? } \\
\text { [Hitler] Tumblr? Eu pareço estar usando um vestido? } \\
\text { [2’33] } \\
\text { Hitler diz: Eu poderia falar com pessoas na vida real, então. Você sabe o quão } \\
\text { cansativo é isso? }\end{array}$ & $\begin{array}{l}\text { Diálogos do filme } \\
\text { na língua original, } \\
\text { o alemão. }\end{array}$ \\
\hline
\end{tabular}

${ }^{13}$ As legendas desse e dos demais vídeos foram traduzidas pelos autores do artigo.

${ }^{14}$ Blogueiro (http://scobleizer.com) cujo nome é associado aos chamados viciados em internet.

${ }^{15}$ Corruptela de tweet people, ou pessoas do Twitter.

${ }^{16}$ Uma outra plataforma de publicação de blog. 


\section{Vídeo 3 - Usain Bolt break 100m world Record and Hitler reacts (Usain Bolt quebra o recorde dos 100 metros e Hitler reage)}

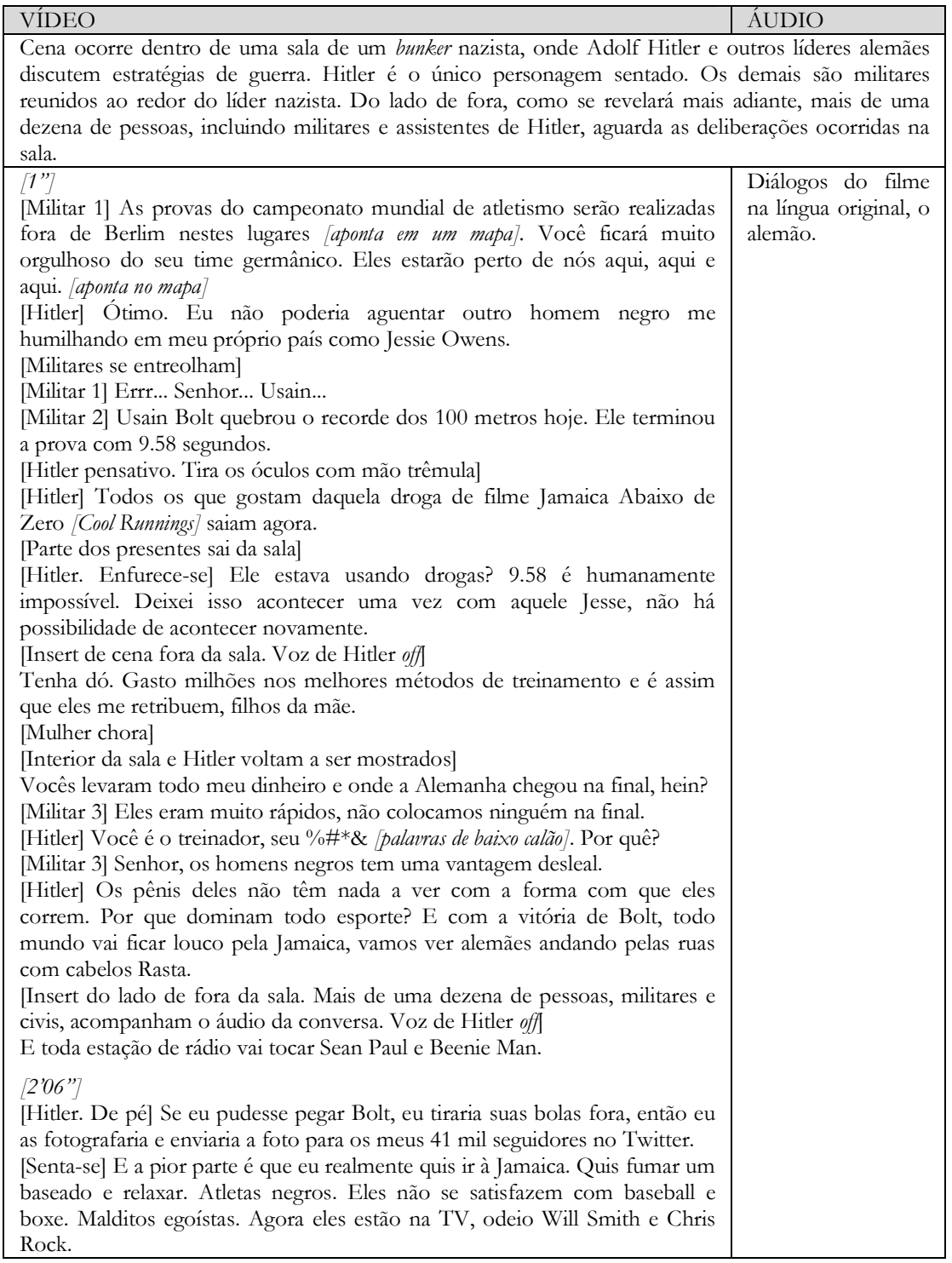

ARAÚJO; COSTA - A fúria do Führer... 


\section{Vídeo 4 - Hitler hates the Jonas Brothers (Hitler odeia os Jonas Brothers)}

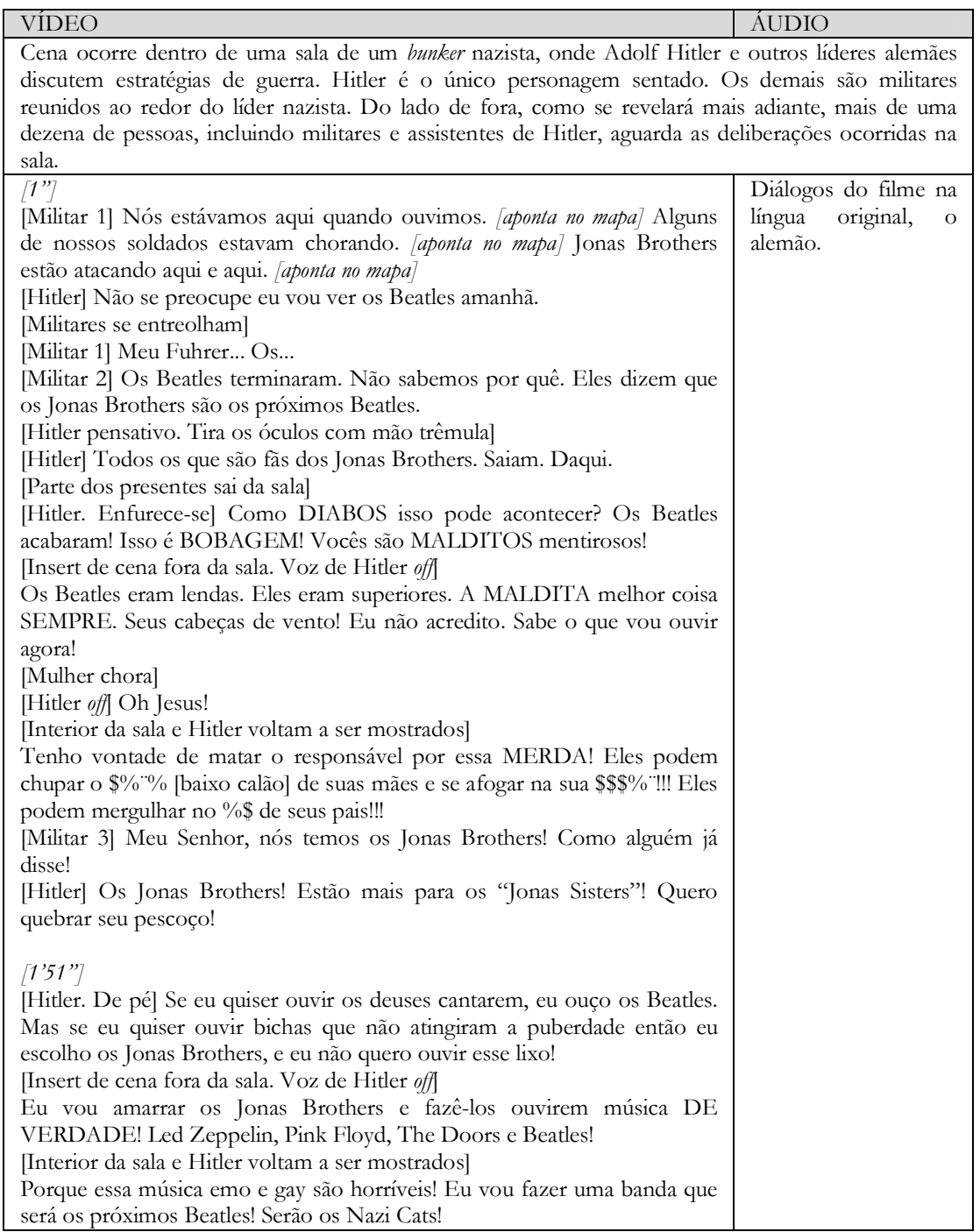


Recebido em: 07/04/11. Aprovado em: 25/07/11.

Title: The Führer's rage: a study of discursive-pragmatic strategies in a viral Youtube video Authors: Júlio César Araújo; Rafael Rodrigues da Costa Abstract: Some theories concerning presupposition (STRAWSON, 1952; KEENAN, 1971) in enunciates and enunciation scenes (MAINGUENEAU, 2008) are revisited in this article, which aims to identify how and where the pragmatic presuppositions appear in a corpus formed by four videos uploaded on Youtube repository. Such videos are part of a viral phenomenon of the internet. All of them reproduce the same scene from the movie The Downfall, adding subtitles in which the original content of the movie is replaced by dialogues about contemporary subjects. The analysis authorizes us to conclude that the Adolf Hitler character, the leading role in the mentioned movie, is transformed via changes in comprehensive and generic scenes, from which it is possible to re-introduce him in certain contexts. In that process, presuppositions emerge in satirical or mocking ways.

Keywords: Enunciative scene. Presupposition. Web 2.0. Viral. Adolf Hitler.

Titulo: La furia del Führer: um studio de las estrategias discursivo-pragmáticas presentes en un "viral" del Youtube

Autores: Júlio César Araújo; Rafael Rodrigues da Costa

Resumen: Algunas teorias sobre presuposición (STRAWSON, 1952; KEENAN, 1971) en enunciados y sobre escenas de enunciación (MAINGUENEAU, 2008) son revisitadas en este articulo, cuyo objetivo es identificar como y donde los supuestos pragmáticos aparecen en un corpus compuesto de cuatro vídeos publicados en el repositorio Youtube. Tales vídeos son parte de un fenómeno viral de la internet y reproducen una misma escena de la pelicula alemana La Caída, agregándole subtitulos en los que el contenido original de la película daa lugar a diálogos sobre temas contemporáneos. El análisis nos autoriza a concluir que la figura de Adolf Hitler, principal personaje del trozo de pelicula reproducido, pasa por un cambio de escenas enunciativas englobantes y genéricas, a partir de la cual es posible reinserirlo en determinados contextos. De esta forma emergen suposiciones que ora lo satirizan, ora lo ridicularizan.

Palabras clave: Escena enunciativa. Presupuesto. Web 2.0. Viral. Adolf Hitler.

ARAÚJO; COSTA - A fúria do Führer... 